\title{
SELF-RECONSTRUCTION THROUGH THE SENSE OF GUILT: A STUDY OF SELECT MASTERPIECES IN THE AMERICAN FICTION
}

\author{
Mugahed Abdulqader Alawi Alheshami ${ }^{1}$ \\ Mohammed Yassin Mohd Aba Sha'ar ${ }^{2}$ \\ ${ }^{1}$ Al-baydha University \\ mugahedabdu@gmail.com \\ ${ }^{2}$ Nakhon Si Thammarat Rajabhat University \\ mohammed_moh@nstru.ac.th
}

\begin{abstract}
Reconstruction is considered as a comprehensive transformation of one's attitude with respect to the individual ego, action; the cause of guilt and the temporal-existential experience. The process of reconstruction stems from the need for improvement of the self. Any human being gets exposed to the feelings of sadness, despair, envy, shame, embarrassment and many other emotions that could leave him psychologically disabled. This paper is going to investigate how the feelings of guilt foster the development of a stable trend towards order and improvement through literary analysis of three selected novels. This paper aims to sheds light on the positive side of the feeling of guilt that can motivate transformation in behaviour. It elaborates how Toni Morrison's in Beloved (1987), Khalid Hosseni's in The Kite Runner (2003) and Nathenial Hawthorn's in The Scarlet Letter (1850) succeeded in their writings to change the negative feelings of guilt into colossal internal power of self-reparation and improvements. The literacy analysis of these revealed that the feeling of guilt has the ability to arouse the values of freedom, justice, self-esteem, confidence and identity reconstruction.
\end{abstract}

Keywords: Guilt, Improvement, Fiction, Culture, Society.

\section{INTRODUCTION}

(Herd, 2013) argued that guilt is in association with the deontic family of concepts, with having committed some offense, or having failed in some duty or responsibility, such that one is now culpable. Guilt can act as a motivator to behaviour but this doesn't mean that it always enhances for virtuous behaviour or character. In most times, guilt helpers aim to reduce or eliminate the feelings of guilt regardless of the virtuous purpose it may be maintained. In this research, we concentrate on the positive side that motivates a transformation in self and actions. Psychologists view that there is an intersection between the feelings of guilt and shame. The feelings of guilt are experienced when the person feels shortcomings in some traits of his personality such as the feelings of shame. These feelings result in symptoms like depression, anger, anxiety and self-blame.

\section{British, Jurnal Bahasa dan Sastra Inggris}


Many critics have dealt with the theme of guilt in the select works but here we want to diagnose the feelings of guilt in upgrading the personality with reference to the main characters in the aforementioned masterpieces. After experiencing such feelings, they have subjected to transformation in their self and behaviour. The three writers have been skilful in handling the theme of guilt and showing how it can affect the thought, feelings and actions. Though they have related the theme of guilt with other themes of shame and sin but the theme of guilt is of more concern to the transformation process. In all of them, the culture, society and rules are related to each other and influence the feelings of guilt. Guilt is described as interpersonal because it is related not only to the person but also to the community. It is regarded as "weapon used by the superego to influence the ego's decisions" (Roy F. Baumeister, 1994, p.2). Despite many psychologists assert that guilt is produced from within not from without, the fact proves that it is too much related to internalized standards of behaviour.

Many scholars regard the guilt and associated feelings as negative experience evoked when a person's behaviour fails to meet the societal standards. David M. Amodio (2007) said that guilt dynamically functions to first provide a negative reinforcement cue associated with reduced approach motivation, which transforms into approach-motivated behaviour when an opportunity for reparation presents itself. Many studies have approved the role of guilt in self-regulation and its importance in organizing the intergroup relationship "it is assumed that guilt increases cooperation because individuals are motivated to reduce the aversive feeling state associated with their guilt. Presumably engaging in cooperative behaviour is an effective means of removing such feelings" (Ketelaar, 2003, p.2). They have also assumed that guilt functions as reparatory to the past transgressions and making them move towards more appropriate future. Its role is not only restricted to the intergroup relationship but it starts to motivate a reparatory motivation for one person's self and that we can see in the core of discussions of the three works.

\section{British, Jurnal Bahasa dan Sastra Inggris}




\section{RESEARCH METHOD}

This article is a descriptive analytic study which aims to concentrate on the feelings of guilt being experienced in the select texts and give an analysis supported by some excerpts that directly refer to the core idea of this article. The topic of this article is too much related to the field of psychology, so it has been necessary to refer to some explanations presented by some psychologists in order to understand the feelings of guilt. In the critical appraisal, we have tried to explain the feelings of guilt which have been experienced differently from one text to another.

\section{RESEARCH FINDING AND DISCUSSION}

The three novelists have been exceptional in including the theme of guilt in their works. They have made victory to the moral values and virtues that should be embodied in the personality of human beings. Feelings of guilt have aroused the values of freedom, justice, self-esteem, confidence and identity reconstruction. Their struggle was in favor of the human dignity and existence. Toni Morrison's Beloved is rememorizing the painful history of slavery to the African Americans and their story from slavery to freedom. This novel narrates a very important period in the history of the USA, which means after the civil war end that is called reconstruction period. Being able to devastate slavery, the black Americans were able to reconstruct the miserable, forgotten history; "reconstruct themselves, their families and their communities" (Beloved, Chapter one, 2001).

Morrison's Beloved narrates the story of a black slave American who kills her daughter in order to save her from the atrocities of slavery that she herself and her husband suffered. With compelling passion, the story upholds a triumph of meekness over savage. Morrison's Beloved focuses on three main points which are slavery, emancipation and reconstruction. It is not only a story of the past but it is the story of how the characters confront the challenges coming in the way of human dignity and an aim to correct the wrong images stereotyped about the black women. Morrison tends to celebrate the legends of black women and allow her characters to recover from the past traumatic memories.

\section{British, Jurnal Bahasa dan Sastra Inggris}


Through the sense of guilt, Toni Morrison described the "neo-slave narratives as residually oral, modern narratives of escape from bondage to freedom". By remembering the past, Morrison broke the long silence regarding enslavement and talks about the oppressed black women. The neo-narrative genre crossed "the boundaries of space, time, history, place, language, corporeality and restricted consciousness in order to make reconstruction and mark or name gaps and absences" (David, 2007). The novel "Beloved" begins with slavery, emancipation and reconstruction. Sethe becomes able to care about her children after escape and experience the maternal feelings. Her rape and beating have never been the barrier, despite the hurtful memories, to break the shackles of oppression, slavery and abuse. In an interview with Toni Morrison, she said that "With Beloved, 1 am trying to insert this memory that was unbearable and unspeakable into the literature. Not only to write about a woman who did what Sethe did, but to have the ghost of the daughter - that she believes is her daughter return, as a remnant, a trace of a period that was unspoken. It was a silence within the race. So it's a kind of healing experience" (Morrison, 1993).

The novel's name is Beloved but most of the critical studies focus on the main character, Sethe, who is changed into a functioning character through the past memories. Though she feels guilty but she sees what she has done is right to save her children from slavery and disrespect as she states, "It's my job to know what is and to keep them away from what I know is terrible. I did that" (Morrison, 1987, p.194). While Sethe is standing with Beloved and Denver and confused with her past memories, Mr. Bodwin who represents the white slave master is attacked. She doesn't attack her children; instead, she shows improvement in her recognition by attacking the attacker not her children. Actually, disappearance of Beloved hints at the moral message and the ultimate purpose of overcoming the past miserable memories and giving chance to emotional and psychological catharsis.

In exposing the sufferings of the African Americans, Morrison unifies all African Americans to be stronger than they were in the past. If the African Americans suffered in the past, it is because they didn't unify themselves against British, Jurnal Bahasa dan Sastra Inggris 
the recurrent violations. Morrison unified the goal of all the African through the sense of guilt; she begins each chapter in the novel in the present, and then returns to the past in order to bridge the gap between occurrences of the past and those of the present:

I don't know, man. Don't look like it to me. I know Sethe's mouth and this ain't it ... Pigs were crying in the chute. All day Paul D, Stamp Paid and twenty more had pushed and prodded them from canal to shore to chute to slaughterhouse. Although, as grain farmers moved west, St. Louis and Chicago now ate up a lot of the business, Cincinnati was still pig port in the minds of Ohioans. (78)

Toni Morrison in Beloved shows the horror of slavery but on the other hand, she raises the question "whether it is possible for the individuals to heal and recover from the trauma?" (Mörk, 2009). From a religious perspective, sins should be confessed and followed by repent for absolving the sins, so Sethe remembers her sin that makes her feel guilty and later she is turned into a functioning person. Mork added that the resurrection of Beloved gives the mother and each individual in the family the opportunity to recognize their position in society and to reconsider their internalized values. For Morison, the heinous, internalized values of violence and unhappiness that some slaves might have, are acquired from the white men "the jungle the blacks brought with them" but to "the jungle white folks planted in them." (234). Accordingly, the harm caused to the slaves leaves too much influence on their psyche, so the psychological rehabilitation takes longer time that could exceed one generation. It is around eighteen years since Sethe killed her baby daughter; so after this long period, her attitude and behaviour have got changed and rightly oriented.

Mork added that love is the main motive through which Sethe heals her psyche from the feelings of guilt. In the first meeting of Sethe with her daughter, the ghost, the feelings of love appear in her speech. Sethe wants to amend her sin after what she has done to her daughter. The feelings of love have been able to make the reader more sympathetic with the criminal, Sethe, because her justification is to prevent enslavement to her children. The feelings of love are the only way and cure to heal the post-slavery racism. Sethe loves her child and 
ethnic community "Sethe pleaded forgiveness, counting, listing again and again her reasons, that Beloved was more important, meant more to her than her own life. That she would trade places any day, give up her life, every minute and hour of it, to take back just one of beloved's tears". (p.241-42). Mario Mikulincer (2018) said that:

The consolidation of an inner sense of attachment security during interactions with supportive attachment figures promotes general faith in other people's good will; a sense of being loved, esteemed, and accepted by relationship partners; and optimistic beliefs about one's ability to cope with stress and manage distress. (5)

In The Scarlet Letter, the theme of guilt is the most dominant and main motive to all the events. Hester is condemned with adultery in the puritan society. She is exposed on the scaffold to the piercing eyes of the public as a punishment and forced to wear the scarlet letter " $A$ " on her chest as a sign of her sin. However, she never succumbs to the community thoughts and scornful gazes at her. She feels guilty of committing sin but not ashamed of her personality. Forcing Hester to wear the scarlet letter leads her to create a beautiful scarlet letter which makes the whole society to believe that she isn't regretful for her sin. The interpretation of the scarlet letter " $A$ " has the possibility of another interpretation, so the sin is changed into ability "They said that it meant able; so strong was Hester Prynne, with a woman's strength" (141). ... Her mother, with the scarlet letter on her breast, glittering in its fantastic embroidery, had long been a familiar object to the townspeople ((Hawthorne, 1850, 150).

Even the people become more convinced that the letter A on her chest is a symbol of power and ability:

The letter was the symbol of her calling. Such helpfulness was found in her-so much power to do, and power to sympathize - that many people refused to interpret the scarlet A by its original signification. They said that it meant Able; so strong was Hester Prynne, with a woman's strength...they had begun to look upon the scarlet letter as the token, not of that one sin, for which she had borne so long and dreary a penance, but of her many good deeds since. $(152,153)$

\section{British, Jurnal Bahasa dan Sastra Inggris}


On the contrary, to Dimmesdale, Hester gets stronger despite the sin whereas Dimmesdale gets weaker and undergoes to mental torment though his sin doesn't appear to public “Mr. Dimmesdale was overcome with a great horror of mind, as if the universe were gazing at a scarlet token on his naked breast, right over his heart. On that spot, in very truth, there was, and there had long been, the gnawing and poisonous tooth of bodily pain" (139).

Both Arthur Dimmesdale and Hester Pryne have committed the same sin which is adultery but the sin has influenced them differently. According to the author, Nathanieal Hawthorne, their sin is only a crime in the eyes of society but it isn't prohibited in all religions. Hester doesn't regard her adultery as sin, so she frankly declares that "What we did had a consecration of its own. We felt it so! We said so to each other!" (p.176). In contrast, Dimmesdale finds himself works under the constraints of society, so the impact of sin has left him in battle with thoughts of guilt, depression and confusion. Living in a society that she isn't accepted in it or part of it enables Hester to have insights that drive her into a change in her disposition and changes the ways of perceiving her sin in her society. She opposes the ideas of puritan patriarchy in a proud, rebellious manner. Hester's rebellious personality is reflected in her stubborn daughter; Pearl whom society regards her as a demon because she is the result of illegal relationship outside of marriage affairs. Hawthorne has granted a sense of power to Hester and her daughter; he doesn't want the end to be sentimental but he grows the feelings of rebellion, challenge and change in the personality of his characters.

Sundstroom, (2004) said that "Hester never criticizes her personal internal person, but she confesses her participation in adultery, for that reason she feels guilty because of her particular behaviour now not because of herself as an individual" (23). The wrong evaluation of one behaviour results with feelings of guilt but the self remains intact; so Hester feels guilty of her behaviour but never feels ashamed. Feelings of shame make the person felt negative about himself and society. Hester makes her sin a starting point towards change and becomes a woman of charity "self-ordained ... sister of mercy ... That it meant able" (141). Guilt is perceived to be social emotion, so Roy F. Baumeister (1994) said "that British, Jurnal Bahasa dan Sastra Inggris 
guilt is something that happens between people rather than just inside them. That is, guilt is an interpersonal phenomenon that is functionally and causally linked to communal relationships between people" (p.1). Hester has dealt with her sin as guilt but not as shame, so she could have managed a reparative action regarding her attitude towards puritans of her society.

Sjo"berg (2009) added that the structure of guilt is divided into two parts; the first part is the moment of guilt and the second is "the moment of negligence". The reconstruction process comes to tie the two elements and make a reevaluation to the action taking place in the moments of negligence. In the reconstruction process, there will be a change in the perspective of one's experience and actions. In the Scarlet Letter, Hester has completely shifted herself from a sinner to a sister of mercy and charity. The good thing is that Hester's feelings of guilt are temporary because if they are permanent, then they will be changed into severe shame. The positive feelings of guilt are in connection to one's voluntary actions which can achieve feelings of reparation over one's whole life. Londhe (2012) said that "Hawthorne is not overly concerned with the sin that has been committed; he is more concerned with the results of the sin". Hawthorne wants to refer to the fact that the sin that is confessed by the sinner is less harmful than the sin being concealed or hidden; the confessed sin can bring change, transformation and repair.

Nathaniel Hawthorne emphasizes on the salvation that comes only from the truth; the truth should be the leader for ideal life through true relationship with people and with God. Despite the fear of sin, Hester has been very brave to her society in saying the truth though she knows well that she has breached the social and religious codes of her society "In all things else, I have striven to be true! Truth was the one virtue which I might have held fast, and did not hold through all extremity ... A lie is never good, even though death threaten on the other side!" (Chapter 24). In telling the truth, all the masks are dropped off and the person becomes more recognized to himself and visible to the others. Pretence, hypocrisy, selfishness and other wicked internal feelings prove to be devastating, hidden powers to an individual and should be abandoned. They lead to mental and British, Jurnal Bahasa dan Sastra Inggris 
physical deterioration. Hester has recognized the negative influences and preferred declaring her sin proudly in front of all the people and attract the respect of public.

In The Scarlet letter, Hawthorne has presented his characters with different natures in dealing with the feelings of guilt. Hester is a shining example of idealness and positivity whereas Dimmesdale and Chillingworth are the examples of imperfection and negativity. Hester Pryne has been able to change negativity into positivity and vulnerability into invulnerability, love and respect. She has adopted reparative plans to maintain her self-esteem and adopts a new identity full of confidence, favourableness and profitableness. Hawthorne's study of guilt is not only concerned with the traditional ideas of what is moral and amoral that brings the story to its conclusion; rather "by turns, the source appears to be the conscience stricken mind reeling from the horror of its sin and then the mind stricken mind tortured by a morbidity of spirit that bears only a shadowy relationship to the exterior event of sin" (Neuman, March, 1966).

In The Scarlet Letter, the sinful mother is happier than the sinful father. Her conscience is more elevated than his. Hester takes care of the daughter who is the result of their sin as considered by the society and doesn't discover the real father of her daughter. In an attempt to avoid the puritan surveillance, she moves with her daughter to live in the wood for some time and work as a seamstress to become financially independent. She sews clothes for the well-off Puritan ladies and then to the poor people. So, she creates a social position in her society as a communal philanthropist (Abdelfattah, 2013). In a reference to the social functions of guilt and shame, (D. Páez, 2006) explains that "Shame encourages pro-social behaviour, conformity and responsibility. Guilt increases compliance and reinforces social bonds, with a sense of interpersonal obligation and empathy" (2). The feelings of guilt have encouraged Hester to reinforce her social bonds with the common people and increases empathy with the poor and needy people. He added that guilt is more related with reparation and apology whereas shame is related with tendencies of escape and hide.

\section{British, Jurnal Bahasa dan Sastra Inggris}


In The Kite Runner written by Khaled Hosseini, the theme of guilt is very prominent. It follows the story of two children who are Amir and Hassan. Amir belongs to Pashtun tribe whereas Hassan is the son of Amir's father's servant. Hassan belongs to the Shia Haraza community. Khaled Hosseini himself said that his novel is a novel of guilt and redemption though many other themes are discussed in this novel: "Because it's themes of friendship, betrayal, guilt, redemption and the uneasy love between fathers and sons are universal, and not specifically Afghan, the book has been able to reach across cultural, racial, religious and gender gaps to resonate with readers of varying backgrounds" (Walia, May, 2017). The novel starts with the flashback technique by narrating past events related to Amir's past life in Afghanistan. His past was full of feelings of guilt and betrayal, so the present and past are blended together.

1 remember the precise moment, crouching behind a crumbling mud wall, peeking into the alley near the frozen creek. That was a long time ago, but it's wrong what they say about the past, I've learned, about how you can bury it. Because the past claws its way out. Looking back now, I realize I have been peeking into that deserted alley for the last twenty-six years. (Hosseini, 2003, p.1)

Amir's friend, Rahim Khan from Pakistan called him to visit him, so this call evoked the past memories in which the sad memories overcome on the sweet memories due to the feelings of guilt that disturb his present "It wasn't just Rahim Khan online. It was my past of unatoned sins.”(1). Amir felt the past with guilt particularly his cruelty against Hassan. Amir felt jealous of Hassan because Amir's father, Baba, considered Hassan as his son though he is publicly known as Ali's son. The fact is that Baba is the real father of Hassan when he made illegal relationship with his servant's wife. Baba didn't dare to claim his fatherhood to Hassan in order to avoid shame in his Pashtun tribe, so Baba amends his sin by taking care of Hassan and considered him as same as his only son, Amir. Herdt, 2013 said that guilt can enrich empathy and thereby foster the development of a secure disposition of benevolence (1).

Actually, Amir, after leaving Afghanistan to live in America, blames no one but his conscience. His migration to the United States of America was like a

\section{British, Jurnal Bahasa dan Sastra Inggris}


moral, spiritual revival, so he frankly expresses his awareness of the cultural mobility that helped him to make attempts of amending his guilt and restructure his identity "America was a river, roaring along, unmindful of the past. I could wade into this river, let my sins drown to the bottom, let the waters carry me someplace far. Some place with no ghosts, no memories, and no sins." (Hosseini 126). Amir remembers when Hassan was raped by Assef after the tournament ended and when Hassan refused to hand over the kite to Assef. Such memories evoked the feelings of guilt especially when Assef is raped and was being watched by Amir and did nothing to save Hassan:

Hassan knew I 'd seen everything in that alley, that I stood there and done nothing. He knew I had betrayed him and yet he was rescuing me once again, maybe for the last time. I loved him in that moment, loved him more than I 'd ever loved anyone, and I wanted to tell them all that I was the snake in the grass, the monster in the lake. I wasn't worthy of this sacrifice. I was a liar, a cheat, and a thief. (p.105)

Being tortured with feelings of guilt, Amir attempted to redeem himself by making a psychological remedy. When his wife Soraya Taheri told him very courageously about her story and elopement with an Afghan man when they were in Virginia, Amir did nothing and admired her courage though she expected him to cancel their marriage "I'm so lucky to have found you. You're so different from every Afghan guy I've met .... I think a big part of the reason why I did not care about Soraya 's past was that I had one of my own. I knew all about regret" (p. 180). The past sin against Hassan has generated the feelings of guilt in Amir's feelings and has become aware of his guilt and its reason. Recognizing his sin is the first step of self-reconstruction and reparation, so Amir says "I wish he would give it right back to me, break the door open and tell me of- it would have made things easier, better" (p. 88). For self-consciousness, the individuals become aware of themselves in relation to others "Our experience of guilt directly reflects our sense of responsibility for the quality of our own agency, and indirectly disposes us to empathy with others (Ibid, 11).

When Rahim Khan is critically ill, he calls Amir to come to Pakistan and tells Amir to go to Kabul in order to take Sohrab who is Hassan's son and tells 
him that Hassan is his brother. Amir feels reluctant to go to Kabul because it is dangerous and says he is ready to pay for anyone who can do the task on his behalf; however, Rahim insists on Amir to go by himself in order to forgive his past sin against Hassan. Initially, he asked him to come in order to amend his sin "Come. There is a way to be good again" (p. 192). When Amir comes to know everything about Hassan as his brother and Baba is his real father, he disgusts his father's sin but soon he realizes that his father and he are similar in their sin, so he forgives his father and says, "Baba and I were more alike than I'd ever known. We had both betrayed the people who would have given their lives for us. And with that came this realization: that Rahim Khan had summoned me here to atone not just for my sins but for Baba's too" (p. 226).

When Amir went to Kabul to take Sohrab back with him to America, he found him in the house of the leading Taliban Assef in order to dance for the Taliban leaders. Assef gets angry of Amir and brutally attacks him to leave him bleeding with injuries. Amir feels moments of redemption and even receives the blows of Assef with laughing because he made analogy between these moments when he is attacked by Assef and being watched by Sohrab and the past moments when Hassan was raped by Assef and Amir did nothing for him though Sohrab came to rescue Amir and shot Assef with slingshots. Amir explains such moments in this quote:

I laughed because I saw that, in some hidden nook in a corner of my mind, I'd even been looking forward to this. I remembered the day on the hill I had pelted Hassan with pomegranates and tried to provoke him. He'd just stood then, doing nothing, red juice soaking through his shirt like blood. Then he'd take the pomegranate from my hand, crushed it against his forehead. Are you satisfied now? He'd hissed. Do you feel better? I hadn't been happy and I hadn't felt better, not all at. But I did now. My body was broken .... But I felt healed. Healed at last. I laughed. (p. 289)

When Amir brought Sohrab to America, the Afghan community shows concern why did Amir bring a Hazra boy and leave him sleep in his house? "They will want to know why there is a Hazara boy living with our daughter. What do I tell them? (p. 360). Amir takes a strong stance against their protest as same as British, Jurnal Bahasa dan Sastra Inggris 
Baba refused to dismiss Hassan out when Amir asked him, so Amir tries to remember the past and make atonement "He is my nephew. That is what you tell people when they ask ... And are more thing, General Sahib ... You will never again refer to him as Hazara boy 'in my presence. He has a name and it's Sohrab\| (p. 361). Khadawardi (2017) said that atonement, redemption and forgiveness took a long time to be achieved" (P.110). The longtime has given Amir a chance for self-reconstruction through the feelings of guilt. In fact, the change in human nature and psychology takes time, so (Marchand, July, 2012) stated that the concepts of change, progress and development are closely related. From the beginning to the end, the themes of sin and redemption are the most leading themes of this story. It started with jealousy, conflict, guilt, and disgust and ended with feelings of love, redemption and healing. Before Amir is seeking redemption, he has to seek inner peace within himself and then begin to do actions since "There's a way to be good again” (P.238). (David M. Amodio, 2007) said that "guilt may function as a reinforcement learning cue as well as an impetus for prosocial egalitarian responses" (p.6). Amir has learnt a lot from his guilt despite his learning took much time to be positive and fruitful to him and to the others.

\section{CONCLUSION AND SUGGESTION}

Feelings of guilt could be negative and devastative; on the other hand, they could be positive and spur one's self reconstruction. The reconstruction process is comprehensive since it includes the attitudes, behaviours and actions though it is different from one society to another and from one culture to another. In many times, the feelings of guilt could be experienced differently by different individuals. Accordingly, their consequences are also varied. In general, the feelings of guilt could be a psychological symptom especially when they are associated with feelings of shame. However, this paper has attempted to focus on the positive aspects of the feelings of guilt on self-development and the possibility of redemption from such feelings and rendering the negative guilty past into positive, influential, fruitful present. The three aforementioned novels belong to

\section{British, Jurnal Bahasa dan Sastra Inggris}


different periods of time and different cultures but all of them have agreed on the possibility of redemption from the negative feelings of guilt.

The three novels are written by great, famous novelists whose aim is to energise their readers with positivity, hope, love and sense of redemption. Many studies have approved the role of guilt in self-regulation and its importance in organizing the intergroup relationship. They have also assumed that guilt functions as reparatory to the past transgressions and making them move towards more appropriate future, so there should be more studies focus on the positive side of guilt to change our behaviour especially in the modern life which is full of symptoms of despair, disappointment and contradictions. This humble research hopes to motivate its readers to search in this field in the hope of overcoming all the odds of life.

\section{REFERENCES}

Beloved, Chapter one. (2001).

Abdelfattah, H. A. (2013). Adultery and Redemption in Nathaniel Hawthorne's The Scarlet Letter (1850)and Graham Greene's The Power and the Glory (1940. Arab World English Journal, 16.

D. Páez, J. M. (2006). Dealing With Collective Shame And Guilt. Psicología Política, $N^{o}$ 32, Mayo 2006, 20.

David M. Amodio, P. G.-J. (2007). A Dynamic Model of Guilt. Implications for Motivation and Self-Regulation in the Context of Prejudice. Psychological Science. Department of Psychology, New York University, New York, 7.

Hawthorne, N. (1850). The Scarlet Letter. Boston: Ticknor, Reed and Fields.

Herdt, J. A. (2013). The Role of Guilt in the Development of Virtue. United States of America, Yale university.

Hosseini, K. (May, 2003). The Kite Runner. UAS: Riverhead Books.

Ketelaar, T and Wing, T, A.(2003). The effects of feelings of guilt on the behaviourof uncooperative individuals in repeated socialbargaining games: An affect-as-informationinterpretation of the role of emotion insocial interaction. Psychology Press Ltd,26.

\section{British, Jurnal Bahasa dan Sastra Inggris}


Khadawardi, H. (February, 2017). Superego Guilt, Redemption and Atonement in Khaled Hosseini's the Kite Runner. International Journal of Humanities Social Sciences and Education (IJHSSE), 12.

Londhe, S. V. (2012). Sin, Guilt, and Regeneration in The Scarlet Letter. Review Of Research Vol.1,Issue.IV/Jan; 12pp.1-4, 4.

Marchand, E. K. (July, 2012). Concept of Psychological Change and development-Historical and modern modern Approaches Evaluated. Research Gate, 33.

Mario Mikulincer, P. R. (2018). A Behavioral Systems Approach to Romantic Love Relationships:Attachment, Caregiving, and Sex. University of California, Davis, Interdisciplinary Center (IDC) Herzliya.

Mörk, M. (Spring term 2009). A Religious and Psychological, Approach to Forgiveness, in Toni Morrison's Beloved, Lund University. ENK01 Literary Seminar. USA: English Studies, The Centre for Languages and Literature.

Morrison, T. (1987). Beloved. America: Alfred A.Knopf Inc.

Morrison, T. (1993, November 2). Toni Morrison's Beloved The Past Achieved Flesh. (A. CARABI, Interviewer)

Neuman, V. (March, 1966). Psychological Allegory in the Scarlet Letter. Columbia: University of British Columbia .

Roy F. Baumeister, A. M. (1994, November 2). Guilt: An Interpersonal Approach. America: American Psychological Association.

Roy F. Baumeister, A. M. (1994). Guilt: An Interpersonal Approach. the American Psychological Association, 25.

Sjo berg, G. K. (11 December 2009). The Experiences of Guilt and Shame:A Phenomenological-Psychological Study. Human Studies. Springer Science and Business Media B.V. 2009, 22.

Sundstroom, N. (2004). Open Guilt and Secret Shame: The Difference between Guilt and Shame as Depicted in the Scarlet Letter. ISSN, 32.

WALIA, R. K. (May, 2017). Quest For Identity And Redemption In Khaled Hosseini's The Kite Runner. ImpacT: International Journal of Research in Humanities, Arts and Literature (IMPACT: IJRHAL), 4.

British, Jurnal Bahasa dan Sastra Inggris 